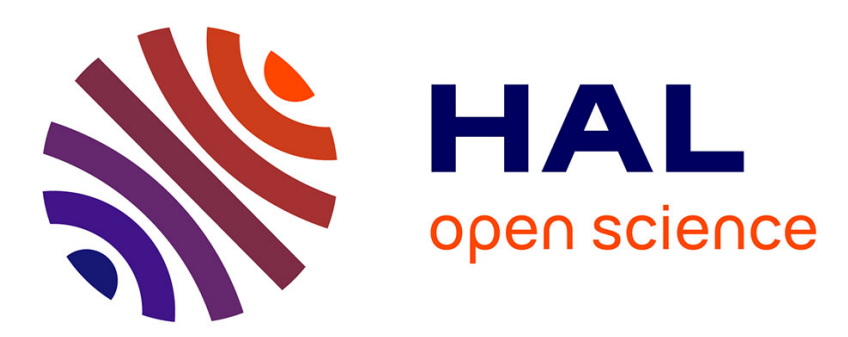

\title{
Hydrocarbon mass balance calculations in petroleum systems experiencing thermochemical sulfate reduction (TSR)
}

Dimitrios Rallakis, Raymond Michels, Alexy Elias Bahnan, Guillaume Barre, Jacques Pironon, Catherine Lorgeoux, Sylvain Calassou, Éric C. Gaucher

\section{To cite this version:}

Dimitrios Rallakis, Raymond Michels, Alexy Elias Bahnan, Guillaume Barre, Jacques Pironon, et al.. Hydrocarbon mass balance calculations in petroleum systems experiencing thermochemical sulfate reduction (TSR). 30th International meeting on Organic geochemistry - IMOG 2021, Sep 2021, Online, France. hal-03429709

\author{
HAL Id: hal-03429709 \\ https://hal.science/hal-03429709
}

Submitted on 15 Nov 2021

HAL is a multi-disciplinary open access archive for the deposit and dissemination of scientific research documents, whether they are published or not. The documents may come from teaching and research institutions in France or abroad, or from public or private research centers.
L'archive ouverte pluridisciplinaire HAL, est destinée au dépôt et à la diffusion de documents scientifiques de niveau recherche, publiés ou non, émanant des établissements d'enseignement et de recherche français ou étrangers, des laboratoires publics ou privés. 


\title{
HYDROCARBON MASS BALANCE CALCULATIONS IN PETROLEUM SYSTEMS EXPERIENCING THERMOCHEMICAL SULFATE REDUCTION (TSR)
}

\author{
Dimitrios Rallakis ${ }^{1}$, Raymond Michels ${ }^{1}$, Alexy Elias Bahnan ${ }^{1}$, Guillaume Barrée ${ }^{2,3}$, \\ Jacques Pironon ${ }^{1}$, Catherine Lorgeoux ${ }^{1}$, Sylvain Calassou ${ }^{3}$ and Eric C. Gaucher ${ }^{3}$ \\ ${ }^{1}$ Université de Lorraine, CNRS, CREGU, GeoRessources lab, Vandœuvre-lès-Nancy, \\ France \\ 2 Université de Pau et des Pays de l'Adour, E2S UPPA, CNRS, TOTAL, LFCR, \\ UMR5150, 64000 Pau, France \\ ${ }^{3}$ Total SA, CSTJF, Avenue Larribau, 64000 Pau, France
}

\section{Introduction}

The quantitative assessment of thermochemical sulfate reduction (TSR) in petroleum systems is to date not entirely understood. Since the term TSR was first established in the 1970's, many equations have been proposed. Each reaction returns very often different numerical results, which reveals the degree of uncertainty. This is highlighted in the present study by evaluating three TSR net equations taken from literature and obtained from experimental studies (Orr, 1974; Goldhaber and Orr, 1995; Worden et al., 1995; Machel, 2001; Mougin et al., 2007; Liu et al., 2013).

The area of study is located in SW France, in the South Aquitaine Basin (Choukroume, 1992; Renard et al., 2019; Elias Bahnan et al., 2020), namely in the Arzacq Basin, where the Lacq petroleum system is located. Apart from the economic importance of the deposit, the area holds great research interest due to the recently revised complex tectonic history. Among major tectonic events, the Lower Cretaceous rift stage is characterized by a hyperextension phase with mantle exhumation (Clerc and Lagabrielle, 2014; Teixell et al., 2018). Such conditions caused very high thermal gradients which rapidly brought source-rocks into the dry gas zone. TSR also occured in the petroleum kitchen areas leading to the consumption of hydrocarbons.

\section{Results}

The organic petrography and Rock-Eval study of the principal source rock in the Arzacq Basin, namely the Kimmeridgian Lons Formation, revealed both type II-S and type-III marine and terrestrial kerogens, respectively.

We aim to evaluate the significance of TSR in hydrocarbon quality/consumption and the development of sour gas in the Deep Lacq petroleum system. The very high level of $\mathrm{H}_{2} \mathrm{~S}$ in Deep Lacq, often reaching $18 \%$ in the total volume of the gas mixture, was used to perform a series of calculations to constrain the mass balance between hydrocarbons generated/destroyed in the source rock kitchen, using the following chemical reaction (Worden et al., 1995; Mougin, 2007; Liu et al., 2013):

$$
\mathrm{CH}_{4(\text { (aq) }}+\mathrm{CaSO}_{4}{ }^{0} \text { (aq.) } \rightarrow \mathrm{CaCO}_{3}{ }^{0}{ }_{\text {(aq.) }}+\mathrm{H}_{2} \mathrm{~S}_{(\text {aq. })}+\mathrm{H}_{2} \mathrm{O}_{(\mathrm{l})}
$$

We have used well data in this equation, namely $40.68 \mathrm{GM}^{3}$ of $\mathrm{H}_{2} \mathrm{~S}$ that correspond to $18 \%$ of the bulk gas composition of the Deep Lacq field upon discovery (total volume in place $=226$ $\mathrm{GM}^{3)}$. Using the stoichiometry of this reaction we have estimated the amount of $\mathrm{CH}_{4}$ needed to produce that amount of $\mathrm{H}_{2} \mathrm{~S}$. 
This method was then used in other regional gas fields in South Aquitaine Basin that were suspicious for TSR. As a next step we have calculated the total amount of hydrocarbons produced in the source rock kitchen in two ways:

1) By summing together the amount of hydrocarbons stored in Deep Lacq plus those consumed by TSR.

2) By calculating the total amount of $\mathrm{CH}_{4}$ generated in the petroleum kitchen*, using the kinetics of the type II and III kerogens of Lons Formation. The calculations were based on the identification of the drainage area using isobath maps, the thickness of the source rock formation focusing on the prolific intervals using sedimentological logs and the average $\mathrm{S} 2$ value from Rock-Eval pyrolysis.

We have then calculated the number of the total hydrocarbons produced in the source rock by comparing the two approaches presented above..

* Due to flash heating all higher homologs were cracked into dry gas very early in the basin history.

\section{Conclusions}

The overall efficiency of the petroleum system including the total amount of hydrocarbons generated, trapped as well as the losses induced by TSR, will be discussed. The reconstructed scenario of fate of hydrocarbons will be confronted to that of the reservoir filling (Elias Bahnan et al., 2020) and the structural evolution of the basin as to contribute to a synthetic model.

\section{References}

Choukroune, P. (1992). Tectonic evolution of the Pyrenees. Annual Review of Earth and Planetary Sciences, 20(1), 143-158.

Clerc, C., \& Lagabrielle, Y. (2014). Thermal control on the modes of crustal thinning leading to mantle exhumation: Insights from the Cretaceous Pyrenean hot paleomargins. Tectonics, 33(7), pp. 1340-1359.

Elias Bahnan A., Carpentier C., Pironon J., Ford M., Ducoux M., Barré G., Mangenot X. and Gaucher E. C. (2020) Impact of geodynamics on fluid circulation and diagenesis of carbonate reservoirs in a foreland basin: Example of the Upper Lacq reservoir (Aquitaine basin, SW France). Marine and Petroleum Geology, 111, 676-694.

Goldhaber, M. B., \& Orr, W. L. (1995). Kinetic controls on thermochemical sulfate reduction as a source of sedimentary $\mathrm{H}_{2} \mathrm{~S}$. Chapter 23, pp. 412-425.

Liu, Q. Y., Worden, R. H., Jin, Z. J., Liu, W. H., Li, J., Gao, B., Zhang, D. W., Hu, A. P. \& Yang, C. (2013). TSR versus nonTSR processes and their impact on gas geochemistry and carbon stable isotopes in Carboniferous, Permian and Lower Triassic marine carbonate gas reservoirs in the Eastern Sichuan Basin, China Thermochemical sulphate reduction (TSR) versus maturation and their effects on hydrogen stable isotopes of very dry alkane gases. Geochimica et Cosmochimica Acta, 100, pp. 96-115.

Machel, H. G. (2001). Bacterial and thermochemical sulfate reduction in diagenetic settings-old and new insights. Sedimentary Geology, 140(1-2), pp. 143-175.

Mougin, P., Lamoureux-Var, V., Bariteau, A., \& Huc, A. Y. (2007). Thermodynamic of thermochemical sulphate reduction. Journal of Petroleum Science and Engineering, 58(3-4), 413-427.

Orr, W. (1974). Changes in sulfur content and isotopic ratios of sulfur during petroleum maturation. Study of Big Horn Basin Paleozoic Oils. AAPG Bulletin, 50, pp. 2295-2317.

Renard S., Pironon J., Sterpenich J., Carpentier C., Lescanne M. and Gaucher E. C. (2019) Diagenesis in Mesozoic carbonate rocks in the North Pyrénées (France) from mineralogy and fluid inclusion analysis: Example of Rousse reservoir and caprock. Chemical Geology, 508, pp. 30-46.

Teixell, A., Labaume, P., Ayarza, P., Espurt, N., de Saint Blanquat, M., Lagabrielle, Y. (2018) Crustal structure and evolution of the Pyrenean-Cantabrian belt: A review and new interpretations from recent concepts and data. Tectonophysics, vol. 724-725, pp. 146-170.

Worden, R. H., Smalley, P. C. and Oxtoby, N. B. (1995). Gas Souring by Thermochemical Sulfate Reduction at $140^{\circ} \mathrm{C} . A A P G$ Bulletin, 79(6), pp. 854-863. 